\title{
CANDI KEDATON MUARA JAMBI DAN NILAI KARAKTER DALAM PEMBELAJARAN SEJARAH: SEBUAH IDENTIFIKASI AWAL
}

\author{
Ida Suryani \\ Pendidikan Sejarah FKIP Universitas PGRI Palembang \\ Email: Ida954321@gmail.com
}

\begin{abstract}
Abstrak
Penelitian ini bertujuan untuk mendeskipsikan nilai karakter pada Candi Kedaton Muara Jambi dalam pembelajaran sejarah. Manfaat Teoritis: Penelitian ini memberikan suatu kajian ilmiah tentang karakter Candi Kedaton Muara Jambi sebagai pengayaan karakter dalam pembelajaran sejarah. Metode yang digunakan dalam penelitian ini adalah dengan menggunakan metode deskriptif kualitatif. Sumber data: a) Informan; b) dokumen; c) tempaat. Teknik pengumpulan data: a) wawancara mendalam; b) Validitas data: adalah teknik triagulasi data, dan triagulasi metode. Teknik analisis: analisis model innteraktif. Penelitian focus pada 1) Pintu gerbang Candi Kedaton; 2) Nilai budaya pada pintu gerbang canDi Kedaton; 3) Nilai karakter pada pintu gerbang Candi Kedaton.
\end{abstract}

Kata kunci: Candi Kedaton, karakter, pembelajaran sejarah.

\begin{abstract}
This study aims to describe the character value of Kedaton Muara Jambi Temple in history learning. Theoretical Benefits: This study provides a scientific study of the character of Kedaton Muara Jambi Temple as an enrichment of character in history learning. The method used in this study is to use a qualitative descriptive method. Data sources: a) Informants; $b$ ) documents; c) temp. Data collection techniques: $a$ ) in-depth interviews; $b$ ) Data validity: is a data triagulation technique, and method triagulation. Analysis technique: analysis of active models. Research focus on 1) Kedaton Temple Gate; 2) The cultural value of the gate canDi Kedaton; 3) Character value at the Kedaton Temple gate.
\end{abstract}

Keywords: Kedaton Temple, character, history learning.

\section{PENDAHULUAN}

Sumatera merupakan salah satu pulau dari enam buah pulau terbesar di dunia dengan luas daratnya sekitar 474.000 kilometer persegi (termasuk kepulauan di setelah dengan luas Barat dan Timur Sumatera). Merupakan pulau besar di bagian barat Nusantara (Utomo, 2012:3). Di daerah wilayah Sumatera tersebarlah wilayah kekuasaan Sriwijaya terutama di wilayah daerah Jambi, ini dibuktikan dengan adanya situs Muara Jambi sesudah terjadinya perubahan dinasti San-Fo-Tsi dari wangsa Syailendra ke wangsan Melayu, ibu kota
San-Fo-Tsi yaitu Swarnabhumi telah berubah menjadi Chu Chiang atau pelabuhan lama yang disebut Po-LinFon. Semenjak keruntuhan dinasti Syailendra Palembang tidak lagi berkedudukan sebagai ibukota (Ismail, 2013: 151).

Muara Jambi merupakan sejarah peninggalan klasik pada masa kerajaan Sriwijaya dan melayu Kuno yang dipergunakan dalam masa yang cukup panjang sejak awal 7 hingga $15 \mathrm{M}$, ini dibuktikan dari kutipan sumber sejarah kekaisaran Cina dan Kerajaan Majapahit yang berpusat di wilayah Jawa Timur. 
Pada tahun $671 \mathrm{M}$, komplek stus percandian Muara Jambi pernah dikunjungi pendeta I-tsing, yang pernah singgah di Shi-li-fo-she (Sriwijaya) dan Mo-lo-yue untuk mendalami bahasa sansekerta selama beberapa bulan untuk berangkat ke Nalanda-India. (Mundardjito, 2009: 1)

Kompleks percandian ini terletak di Kecamatan Muara Sebo, Kabupaten Muara Jambi, Indonesia tepatnya di tepi sungai batang Hari, sekitas 26 kilometer arah timur Kota Jambi di pinggir sungai BatangHari (Ismail, 2003: 153).

Candi Kedaton merupakan Candi terbesar di antara candi-candi yang lain di Kompleks Percandian Muara Jambi. Candi ini baru mulai ditampakkan pada tahun 1979. Letaknya sekitar 900 meter sebelah tenggara Candi Koto Mahligai, atau sekitar 1.580 meter di sebalah barat Candi Gedong II. Sungai Jambi yang merupakan pecahan dari Sungai Amburan Jalo beranda 60 meter di Selatan, sedangkan 70 meter sebelah utara candi mengalir Parit Buluh yang juga berhubungan dengan Sungai Jambi. Candi Kedaton Memiliki luas 45.000 meter persegi, atau sekitar 4,6 hektar, dengan pagar keliling yang membatasinya berukuran $215 \times 250$ meter (Purwanti, 2013: 18).

\section{METODE PENELITIAN}

Metode yang digunakan dalam penelitian ini adalah dengan menggunakan metode deskriptif kualitatif. Sumber data: a) Informan; b) dokumen; c) tempaat. Teknik pengumpulan data: a) wawancara mendalam; b) Validitas data: adalah teknik triagulasi data, dan triagulasi metode. Teknik analisis: analisis model innteraktif.

\section{HASIL DAN PEMBAHASAN}

Letak Candi Kedaton Muara Jambi

Candi Kedaton baru mulai ditampakan pada tahun 1979. Letaknya sekitar 900 meter sebelah barat candi Gedong II. Candi kedaton merupakan candi terbesar diantara candi-candi yang lain di kompleks percandian muara jambi. Candi ini baru mulai ditampakan pada tahun 1979. Letaknya sekitar 900 meter sebelah tenggara candi koto mahligai, atau sekitar 1.580 meter. Sungai jambi yang merupakan pecahan dari sungai Amburan Jalo berada 60 meter di Selatan, sedangkan 70 meter sebelah utara candi mengalir parit buluh yang juga berhubungan dengan sungai jambi (Purwanti, 2013: 18-19).

Lingkungan sekitar candi ini masih sangat alami, karna itu perlu penataan situs. Selain itu kegiatan penelitian dan pelesatarian secara intensif, sebelum situs ini dikembangkan dan diimanfaatkan karna itu pengamanan di daerah ini perlu diberi prioritas tinggi (Mundardjito: 2009:26). 
Candi Kedaton memiliki luas 45.000 meter persegi, atau sekitar 4,6 hektar, dengan pagar keliling yang membatasinya berukuran 215x250 meter. Pada halaman pertama di sisi kiri dari arah pintu masuk terdapatkolam. Dihalamanya candi kedaton ini terdapat tembok-tembok penyekat yang membagi halaman paling sedikit menjadi 9 halaman. Sistem pembagiannya terrdapat di Candi Gempung, candi induk dan candi perwara berada di halaman terbesar yaitu halaman VI. Selain candi induk dan perwara, pada kompleks percandian kedaton ini juga masih terdapat Sembilan bangunan kuno lagi yang belum ditampakan. Salah satu yang belum ditampakan diantaranya berada di halaman I yang di perkirakan sebagai gapura, sehingga timbul asumsi bahwa orientasi kompleks candi kedaton sebenarnyaa menghadapke utara (Purwanti, 2013:18-19).

Nilai Budaya Pintu Gerbang Candi Kedaton

Nilai budaya merupakan nilai yang terkandung dalam nilai sebuah kebudayaan dan unsur-unsur yang membedakan dar kebudayaan lain. Nilai budaya merupakan tinggkat tertinggi dan abstrak dari adat istiadat serta memberikan cirii dari karakter bangsa, suku bangsa, dan kelompok-kelompok masyarakat. Dengan demikian ada perbedaan dengan nilai dan sistem kebudyaan. Nilai budaya tersebut meresapi hidup anggota masyarakat sejak dini sehingga mengakar di dalam jiwa. Karna nilai budaya yang terdapat di suatu kebudayaan tidak dapat digantikan dalam waktu singkat dengan nilai budaya lain (Ritonga, 2012:249).

Dalam kebudayaan yang terdapat di candi Kedaton Muara Jambi, memiliki kontak antara kebudayaan Indonesia dengan kebudayaan Hidu-Buddha yang berasal dari Indiia telah menghasilkan kekayaan seni Indonesia yang beraneka ragam. Pengaruh itu berlangsung cukup lama yaitu dari abad pertama sampai abad ke-15. Pengaruh kebudayaan tersebut sangat terasa di daerah Jawa, Bali, Kalimantan dan Sumatera. Di daerah-daerah tesebut tersebut peinggalan-peniggalan sejarah dari masa pengaruh Hindu-Buddha yang berupa candi-candi sebagai bangunan keagamaan (Darini, 2016:56).

Pintu gerbang Candi Kedaton mempunya ukuran masing-masing sebagai berikut:

1. Gerbang utama jumlahnya 1 yaitu jumlah anak tangga sebanyak 11 anak tangga yang memiliki ukuran tinggi masigmasing $20 \mathrm{~cm}$, dan lebar anak tangga $86 \mathrm{~cm}$. Di sisi kiri dan kanan yang terdapat hiasan bunga teratai memiliki lebar $260 \mathrm{~cm}$. Lebar tiang tangga antara sisi kiri dan kanan $560 \mathrm{~cm}$. pada tiang tangga antara sisi kiri dan kanan 562. Pada tiang 
tangga masing-masing memiliki lebar yang sama antara $48 \mathrm{~cm}$. Tinggi yang dimiliki sebuah makara pafda sisi tangga $121 \mathrm{~cm}$.

2. Pintu gerbang kecil berjumlah 9 yakni setiap sisi pintu yang berada di dalam candi kedaton memiliki ukuran sama yaitu lebar $565 \mathrm{~cm}$, tinggi sisi candi bagian tangga atas $55 \mathrm{~cm}$, lebar bangunan gerbang tiang candi $214 \mathrm{~cm}$, tinggi anak tangga-tangga pertama $35 \mathrm{~cm}$, lebar anak tangga $105 \mathrm{~cm}$, dan tinggi anak tangga $20 \mathrm{~cm}$

\section{Fungsi Pintu Gerbang Candi Kedaton}

Pintu gerbang berfungsi sebagai penghubung antara bangunan dengan jalan. Pintu ini digunakan untuk jalan keluar masuk kendaraan dan manusia. Pintu gerbang adalah bagian dari macam-macam pintu menurut fungsinya. Fungsi utama dari sebuah pintu gerbang adalah media keluar masuk kendaraan atau manusia, yang berada pada posisi terdepan sebuah rumah tinggal dan lansung menghubungkan antar ruaang luar rumah tinggal (jalan raya) dengan halaman depan (Junianto, 2016:8).

\section{Nilai-nilai Karakter dalam Materi Candi}

\section{Muaro Jambi}

Pendidikan karakter sebagai upaya yang disengaja dan terfokus untuk membantu siswa memahami, peduli dan bertindak berdasarkan nilai-nilai etis dan sebagai pengajaran siswa untuk kebaikan, mencintai hal yang baik, dan melakukan kebaikan. Karakter sebagai suatu ciri khas berkaitan erat dengan akhlak (Kuswono, 2017).

Pintu gerbang candi Muaro Jambi memiliki nilai budaya yang dapat dijadikan sumber pendidikan karakter bermuatan lokal dalam pembelajaran sejarah. Penggalian nilai karakter dari sumber budaya lokal akan memudahkan bagi siswa dalam mengembangkan daya afeksinya atas informasi kesejarahan dan kebudayaan yang mereka dapatkan. Nilai-nilai tersebut diantaranya:

Toleransi Budaya telah ditunjukan oleh nenk moyang bangsa Indonesia yaitu mereka mensikapi berbagai budaya asing yang masuk dan berkembang seperti budaya yang dibawa pada masa kerajaan Hindu-Budha.

Menghargai Karya Seni/Keindahan. Wujud menghargai karya seni/keindahan yaitu dengan tetap mempertahanankan keberadaan dari Candi Muaro Jambi, terutama dapat dilihat dari nilai sejarah dan budaya pintu gerbang Muaro Jambi. Mencintai Sejarah dan Budaya Lokal. Pintu gerbang muaro jambi mengajarkan kita bagaimana nilai-nilai budaya yang dimiliki bangssa inndonesia pada masa kerajaan Hindu Budha.

Religius. Pintu gerbang muaro jambi mampuu menggambarkan karakter religious penghuninya. Hal tersebut 
dapat dilihat dari ornamen-ornamen keagamaan yang disematkan dengan unsur ragam hias seni ukir pada pintu gerbang candi muaro jambi yang sangat beragam.

\section{KESIMPULAN}

Berdasarkan uraian diatas, dapat disimpulkan sebagai berikut:

1) Pintu gerbang candi kedaton adalah salah satu nilai budaya yang tertinggi pada masa persebaran agama Buddha yang berasal dari abad ke 9-12 Masehi.

2) Nilai budaya pintu gerbang candi Kedaton Muara Jambi dapat dijadikan sumber karakter pembelajaran sejarah

3) Nilai karakter yang dappat diangkat dari pintu gerbang candi kedaton yaitu : Karakter toleransi budaya, karakter menghargai karya seni/keindahan, karakter mencintai sejarah dan budaya lokal, karakter religius.

\section{DAFTAR PUSTAKA}

Darini, Ririn. (2016). Sejarah Kebudayaan Indonesia Hindu-Budha. Yogyakarta: Ombak.

Ismail, Arlan. (2003). Periodesasi Sejarah Sriwijaya. Palembang: Unanti Press.

Junianto. (2016). Struktur Bangunan Gerbang Kawa Tengkurep sebagai Sumber Pembelajaran Sejarah Kelas XI SMA Puspita Cinta Manis
baru.Palembang: FKIPUniv. PGRI Palembang.

Kuswono, K., \& Khaeroni, C. (2017). Pengembangan modul sejarah pergerakan indonesia terintegrasi nilai karakter religius. HISTORIA: Jurnal Program Studi Pendidikan Sejarah, 5(1), 31-44.

Mundardjito. (2009). Muara jambi Dulu, Sekarang, dan Esok. Palembang: Balai Arkeologi.

Purwanti,Retno. (2009). Muara jambi Dulu, Sekarang, dan Esok. Palembang: Balai Arkeologi.

Ritonga, sakti. (2012). Orientasi Nilai Budaya dan Potensi Konflik Sosial Batak Toba Muslim dan Kristen di Sumatera Utara. Jurnal Vol XII, No 02 Desember 2012.

Utomo, Bambang Budi. (2011). Kebudayaan Zaman Klasik Indonesia di Batang Hari. Jambi: Dinas Kebudayaan dan Pariwisata. 
Nilai Budaya Pintu Gerbang Candi Kedaton Muara Jambi Sebagai..., Ida Suryani, 231-235 